\title{
The Relationship Between Plasma MicroRNAs and Serum Mercury Levels in Patients with Amalgam Filling and Dentists
}

\author{
Makbule Tuğba Tunçdemir(0000-0002-0608-3412) ${ }^{\alpha}$, Fatma Hümeyra Yerlikaya(0000-0002-6606-6593) ${ }^{\beta}$
}

Selcuk Dent J, 2021; 8: 736-743 (Doi: 10.15311/selcukdentj.800849)

Basvuru Tarihi: 28 Eylül 2020 Yayına Kabul Tarihi: 04 Ocak 2021

\begin{abstract}
The Relationship Between Plasma MicroRNAs and Serum Mercury Levels in Patients with Amalgam Filling and Dentists

Background: The aim of this study was to investigate the relationship between serum mercury and some plasma microRNA (miRNA) levels associated with neurological diseases in patients with amalgam filling and dentists.
\end{abstract}

Methods: This study included 30 patients with amalgam filling, 30 dentists, and 30 healthy individuals as the control group. Circulating plasma miRNAs (124-3p, 125-5p, and 127-3p) were evaluated using real-time quantitative polymerase chain reaction analysis. The serum mercury levels were measured using inductively coupled plasma-mass spectrometry. ANOVA and Tukey's multiple comparison tests were used for statistical analyses $(\alpha=.05)$.

Results: A significant difference in serum mercury and plasma miRNA levels was found between the groups. Significant positive correlations between serum mercury and plasma miRNA 125-5p and 127-3p levels were detected in the patient group ( $r$ : 0.56 and $r$ : 0.39 , respectively). Serum mercury and plasma miRNA-125-5p levels showed a positive correlation in the dentist group ( $r: 0.37$ ).

Conclusion: Having amalgam filling caused a significant increase in serum mercury and some plasma miRNA levels (124-3p, 125-5p, and $127-3 p)$. The presence of a positive correlation suggests that sensitivity to neurological diseases may increase because of mercury exposure. Alternative restorative materials should be preferred for amalgam filling and amalgam fillings should be replaced with other restorative materials under necessary preventions.

\section{KEYWORDS}

Dental amalgam, Mercury, MicroRNAs, Neurological disease, Restorative material

Dental amalgam has been used for restorative purposes for many years. Its advantages include its physical and mechanical properties, stability, easy application, and relative affordability compared with directly applied composite restorative materials. ${ }^{1}$ One of the most serious concerns about dental amalgam is that it can be harmful to the human body and nature because it contains mercury. ${ }^{1}$ Mercury vapor released when making and removing amalgam has been reported to show side effects on patients, dentists, and staff. ${ }^{1,2}$ Whether these levels are safe enough remains unclear. ${ }^{3}$ Neghab et al. reported that, the urinary concentration of mercury in dentists was significantly higher than the

\section{öz}

Amalgam Dolgulu Hastalarda ve Diş Hekimlerinde Plazma MikroRNA'lar ile Serum Civa Düzeyleri Arasındaki İlişki

Amaç: $\mathrm{Bu}$ çalışmanın amacı, amalgam dolgusu olan hastalarda ve diş hekimlerinde serum civa ve nörolojik hastalıklarla ilişkili bazı plazma mikroRNA (miRNA) seviyeleri arasındaki ilişkiyi araştırmaktır.

Gereç ve Yöntemler: Bu çalışmaya 30 amalgam dolgulu hasta, 30 amalgam dolgusu olmayan diş hekimi ve 30 sağlıklı kontrol grubu dahil edildi. Dolaşımdaki plazma miRNA'lar (124$3 p, 125-5 p$ ve 127-3p), gerçek zamanlı kantitatif polimeraz zincir reaksiyonu analizi kullanılarak değerlendirildi. Serum civa seviyeleri, endüktif olarak eşleşmiş plazma-kütle spektrometresi kullanılarak ölçüldü. İstatistiksel analizler için ANOVA ve Tukey'in çoklu karşılaşııma testleri kullanıldı $(\alpha=$ .05).

Bulgular: Gruplar arasında serum civa ve plazma miRNA seviyelerinde anlamlı bir fark bulundu. Hasta grubunda serum civa ile plazma miRNA $125-5 p$ ve $127-3 p$ seviyeleri arasında anlamlı pozitif korelasyonlar tespit edildi (sırasıyla r: 0.56 ve $r$ : 0.39). Serum civa ve plazma miRNA-125-5p seviyeleri, diş hekimi grubunda pozitif bir korelasyon gösterdi ( $r: 0.37)$.

Sonuç: Amalgam dolguya sahip olmak serum civa ve bazı plazma miRNA düzeylerinde önemli bir artışa neden olmuştur. Pozitif bir korelasyonun varlığı, civa maruziyeti nedeniyle nörolojik hastalıklara duyarlıı̆ın artabileceğini göstermektedir. Amalgam dolgu için alternatif restoratif materyaller tercih edilmeli ve amalgam dolgular, gerekli önlemler alınarak diğer restoratif materyaller ile değiştirilmelidir.

\section{ANAHTAR KELIMELER}

Civa, Dental amalgam, MikroRNA, Nörolojik hastalık, Restoratif materyal

general practitioners. Additionally some symptoms such as muscular, neuropsychological, cardiovascular, respiratory and dermal were more prevalent in dentists. ${ }^{4}$ It has been reported that; occupational mercury exposure in dentists is associated with the increase of prevalence of intoxication symptoms. ${ }^{4}$ On the other hand; a meta analysis showed a low prevalence of neuropsychological deficits in occupationally mercury exposed persons compared with non-exposed workers. ${ }^{5}$

Some examples of the side effects of mercury in amalgam are associated with chronic fatigue, loss of

\footnotetext{
${ }^{\alpha}$ Necmettin Erbakan University, Faculty of Dentistry, Department of Restorative Dentistry Konya, Turkey.

$\beta$ Selcuk University, Faculty of Medicine, Department of Biochemistry Konya, Turkey.
} 
strength, epilepsy, migraine, blindness, multiple sclerosis, and Alzheimer's disease (AD) ${ }^{6-9}$ Blood mercury levels were found to be statistically higher in patients with Alzheimer's than in the control group. When associated with the number of amalgams, mercury level was higher in patients with one or more amalgams in the mouth than in those without, but this difference was not statistically significant. ${ }^{10}$ Some researchers have suggested that an increase in mercury in the blood of a fetus or baby could be a potential cause of neurodevelopmental barriers. ${ }^{2}$

Individuals who have not been exposed to mercury vapor for a long time are expected to have whole blood mercury levels below $10 \mu \mathrm{g} / \mathrm{L}$ (50 nmol/L)..$^{11-14}$ This value may increase when exposed to mercury vapor for a long time. As soon as exposure to mercury vapor ceases, mercury level in the blood and urine decreases, but the amount of mercury that accumulates in organs which those in the central nervous system (CNS), may still be high. ${ }^{15}$

Demonstrating the effects of microRNA (miRNA) in neurological diseases is not only helpful in understanding the etiology and pathophysiology of these diseases but also in developing more effective diagnosis and treatment methods. Abnormal miRNA functions have been reported to cause neurodegeneration. ${ }^{16,17}$ One of the important miRNAs specific to the nervous system is miR-124. ${ }^{18}$ The expression of miR-124 is enhanced in neurons, and its expression level rises over time in the advancing nervous system. ${ }^{19-21}$ Furthermore, miR-125b-5p is part of a group of miRNAs that act as cahnges from the multiphase to neuron differentiation by inhibiting multiple and differential mRNA targets. ${ }^{22}$ miR-127-3p has also been explained as a neuron-enriched miRNA playing a critical role in neuronal differentiation in the CNS. ${ }^{20,23}$

There is no restriction on the use of amalgam fillings in Turkey. Some information about amalgam filling obtained through television, newspaper, social media etc. causes patients to approach amalgam filling cautiously. However, the use of amalgam filling is still widely used in rural areas. To our knowledge, no study has yet evaluated the relationship between miRNA and amalgam filling in the literature. Thus, this study aimed to evaluate the relationship between the expression levels of some miRNAs, which are associated with neurological disorders (miR-124-3p, miR-125-5p, and miR-127-3p) and the serum mercury levels of patients with amalgam fillings and dentists who are occupationally exposed to elemental mercury.

\section{MATERIALS AND METHODS}

The study was carried out in accordance with the principles of Declaration of Helsinki.
Participants: This study was approved by the local ethics committee (date: May 15, 2019; no: 2019/211). Written and verbal consent was obtained from all the participants. The groups were as follows: 30 patients with at least one amalgam filling for at least five years in their mouths, 30 dentists who preferred to make amalgam filling and had no amalgam filling, and 30 healthy individuals without any amalgam filling as the control group. Patients and healthy participants consisted of individuals who came to the Necmettin Erbakan University Department of Restorative Dentistry for treatment. Characteristic data of all participants are presented in Table 1.

Table 1.

\section{Demographic characteristics of participants}

\begin{tabular}{|c|c|c|c|}
\hline & $\begin{array}{l}\text { Patients with } \\
\text { amalgam filling } \\
(n=30)\end{array}$ & Dentists $(n=30)$ & Control $(n=30)$ \\
\hline \multirow{2}{*}{ Age (years) } & $33.9 \pm 5.6$ & $31.6 \pm 5.4$ & $34.3 \pm 6.2$ \\
\hline & $\min : 23, \max : 44$ & $\min : 25, \max : 43$ & $\min : 25$, max: 44 \\
\hline Sex (male/female) & $19 \mathrm{~F}, 11 \mathrm{M}$ & $22 \mathrm{~F}, 8 \mathrm{M}$ & $12 \mathrm{~F}, 18 \mathrm{M}$ \\
\hline \multirow{2}{*}{ Number of filling } & $2.6 \pm 1.1$ & \multirow{2}{*}{-} & \multirow{2}{*}{ - } \\
\hline & $\min : 1, \max : 7$ & & \\
\hline \multirow{2}{*}{$\begin{array}{l}\text { Professional working } \\
\text { years }\end{array}$} & & $8.5 \pm 5.02$ & \multirow{2}{*}{ - } \\
\hline & & $\min : 2, \max : 21$ & \\
\hline
\end{tabular}

F: Female, M: Male

The exclusion criteria of this study were systemic diseases such as: diabetes, hypertension, malignant diseases, chronic liver disease, cardiovascular disease, infectious diseases, pregnancy, alcohol and smoking habits, and using vitamin supplements, minerals, antioxidants, and fish oil tablets. The researchers examined the mercury content in the body in urine, blood, and hair samples. ${ }^{24}$ Blood samples collected under the conditions of the Faculty of Dentistry were transferred to the laboratory in this study. ${ }^{25}$ Blood samples were obtained after overnight fasting and placed into plain vacuum tubes and EDTA tubes. Plasma and serum samples were obtained after a suitable centrifugation and stored frozen at $-80^{\circ} \mathrm{C}$ until the day of study.

Measurement of miRNA expression levels: The miRNAs targeted from the participants' blood samples (miR-124-3p, miR-127-3p, and miR-125-5p) were studied. RNAs were isolated from the plasma samples using the RTA miRNA isolation kit (RTA Lab, Kocaeli, Turkey). The RNA samples were then converted to cDNA using the oneScript cDNA synthesis kit (ABM, Richmond, BC, Canada). The cDNA samples were preamplified using Poly (A) Polymerase Yeast (ABM, 
Richmond, BC, Canada). The cDNA samples were pre-amplified using Poly (A) Polymerase Yeast (ABM, Richmond, BC, Canada). Quantitative real-time polymerase chain reaction analysis was performed using the BrightGreen miRNA qPCR MasterMix (ABM, Richmond, BC, Canada) on a Light Cycler 96 System (Roche Life Science, Mannheim, Germany). The relative gene expression was determined with the comparison of cycle times for the target PCR using the following formula: relative gene expression = $2^{-(\Delta C \text { tsample }-\Delta \text { Ctcontrol) }}$

Measurement of serum mercury levels: The serum mercury levels were calculated using inductively coupled plasma-mass spectrometry (Thermo Scientific ICAPQC, USA). All analyses of serum mercury levels were performed at once after all samples were taken and carried to the Yozgat Bozok University Science and Technology Application and Research Center (Occupational and Environmental Toxicology Laboratory) on dry ice. The parameters that used in this study were: radiofrequency power of $1550 \mathrm{~W}$, nebulizer gas of $0.96 \mathrm{~L} / \mathrm{min}$, plasma gas of $0.88 \mathrm{~L} / \mathrm{min}$, nebulizer pressure of $3.01 \mathrm{bar}$, dwell time of $0.01 \mathrm{~ms}$, and spray chamber temperature of 3.7 oC. The sampler probe was washed between injections by rinsing with ultrapure water for $30 \mathrm{~s}$, followed by washing with $2 \% \mathrm{HNO}_{3}$ for $45 \mathrm{~s}$ and then rinsing with ultrapure water for $45 \mathrm{~s}$. Each measurement was repeated three times for the average result. Serum sample of $0.25 \mathrm{~mL}$ was digested in teflon vessels with $5 \mathrm{~mL}$ suprapure $\mathrm{HNO}_{3}$ $5 \mathrm{~mL}$ deionized water in a microwave oven (Milestone D5, USA). The clear supernatant was transferred to polypropylene tubes and diluted to $20 \mathrm{~mL}$ with deionized water after cooling.

Statistical analyses: SPSS v. 21.0 (SPSS Inc., IL, USA) programme was used for statistical analyses. Groups of data were compared using ANOVA and Tukey's multiple comparison test. The correlations between serum mercury and the plasma miRNA variables were determined by Pearson's correlation test. All results are presented as the mean \pm standard errors. Confidence interval was determined as $p<0.05$.

\section{RESULTS}

No significant differences were observed in the serum mercury and plasma miR-124-3p, miR-125-5p, and miR-127-3p levels in the groups according to age and gender $(p>0.05)$.

The serum mercury and plasma miRNA levels of the groups are presented in Table 2.
Table 2.

Comparison of groups by serum mercury and plasma miRNA levels: ANOVA test results

\begin{tabular}{|c|c|c|c|c|c|c|c|}
\hline & $\begin{array}{l}\text { Patients } \\
\text { with } \\
\text { amalgam } \\
\text { filling } \\
(n=30)\end{array}$ & $\begin{array}{l}\text { Dentists } \\
(\mathrm{n}=30)\end{array}$ & $\begin{array}{l}\text { Control } \\
(\mathrm{n}=30)\end{array}$ & P* & $p * *$ & $P^{* \star \star *}$ & $\begin{array}{l}\text { Anova } p \\
\text { level }\end{array}$ \\
\hline $\mathrm{Hg}$ & $5.84 \pm 0.13$ & $5.33 \pm 0.08$ & $5.25 \pm 0.09$ & 0.001 & 0.872 & 0.004 & 0.003 \\
\hline $\begin{array}{c}\text { miR } 124- \\
3 p\end{array}$ & $9.13 \pm 1.44$ & $0.99 \pm 0.20$ & $0.92 \pm 0.10$ & $<0.001$ & 0.998 & $<0.001$ & $<0.001$ \\
\hline $\begin{array}{c}\text { miR } 125- \\
5 p\end{array}$ & $0.92 \pm 0.23$ & $0.15 \pm 0.02$ & $0.09 \pm 0.01$ & $<0.001$ & 0.936 & $<0.001$ & $<0.001$ \\
\hline $\begin{array}{l}\operatorname{miR} 127- \\
3 p\end{array}$ & $8.87 \pm 1.35$ & $1.84 \pm 0.43$ & $1.39 \pm 0.22$ & $<0.001$ & 0.923 & $<0.001$ & $<0.001$ \\
\hline
\end{tabular}

None of the subjects had mercury values above the upper limit. According to the ANOVA results, a statistically significant difference was found between the serum mercury levels and the levels of plasma miR-124-3p, miR-125-5p, and miR-127-3p ( $p<$ 0.001 ). The levels of serum mercury and plasma miR-124-3p, miR-125-5p, and miR-127-3p of the group of patients with amalgam filling were significantly higher than those of the dentist and control groups.

The results of Pearson's correlation test are shown in Table 3.

Table 3.

Pearson's correlation test results of serum mercury and plasma miRNA levels

\begin{tabular}{|c|c|c|c|}
\hline & miRNA 124-3p & miRNA $125-5 p$ & miRNA $127-3 p$ \\
\hline $\begin{array}{l}\text { Patients with amalgam } \\
\text { filling }(n=30)\end{array}$ & $\begin{array}{l}r: 0.264(p: \\
0.159)\end{array}$ & $\begin{array}{l}\mathrm{r}: 0.563^{*}(\mathrm{p}: \\
0.001)\end{array}$ & $\begin{array}{l}\mathrm{r}: 0.398^{*}(\mathrm{p}: \\
0.029)\end{array}$ \\
\hline Dentists $(n=30)$ & $\begin{array}{c}r: 0.323(p: \\
0.081)\end{array}$ & $\begin{array}{c}r: 0.379^{*}(p: \\
0.039)\end{array}$ & $\begin{array}{c}r: 0.128(p: \\
0.500)\end{array}$ \\
\hline Control $(n=30)$ & $\begin{array}{c}r:-0.105(p: \\
0.582)\end{array}$ & $\begin{array}{c}r:-0.140(p: \\
0.460)\end{array}$ & $\begin{array}{c}r: 0.0844 \text { (p: } \\
0.657)\end{array}$ \\
\hline
\end{tabular}

No correlation was found betsween the serum mercury level and the plasma miR-124-3p level in all groups. Significant positive associations were observed between the serum mercury level and the plasma miR-125-5p and miR-127-3p levels in the group of patients with amalgam filling ( $r$ : 0.56 and $r$ : 0.39 , respectively). Significant positive associations were found between the serum mercury level and the plasma miR-125-5p level in the dentist group ( $r$ : 0.37 and p: 0.03 , respectively). No correlation was detected between the serum mercury level and the plasma miR-127-3p level in the control and dentist groups.

In the group of patients with amalgam filling, no relationship was found between the number of amalgam fillings and the levels of serum mercury and plasma miR-124-3p, miR125-5p, and miR127$3 p$ ( $p: 0.263, p: 0.755, p: 0.859$, and p: 0.733 , respectively). 
Professional working years were categorized into two groups, namely 10 years-below and over 10 years, and both groups had 15 dentists each. No relationship was found between professional working years and the levels of serum mercury, plasma miR-124-3p, miR-125$5 p$, and miR127-3p ( $p>0.05, p: 0.257, p: 0.762, p:$ 0.197 , and $p: 0.764$, respectively).

The frequency of making amalgam filling of dentists was also recorded and categorized into three groups: 3-5 per month, 3-5 per week, and more often. No relationship was found between the frequency of making amalgam filling and the levels of serum mercury, plasma miR-124-3p, miR125-5p, and miR127$3 p$ ( $p>0.05$, p: 0.577, p: 0.694, p: 0.702, and p: 0.112, respectively).

\section{DISCUSSION}

This study determined whether serum mercury and plasma miRNA levels were associated with neurological degeneration in patients with amalgam fillings and dentists who make amalgam filling. Amalgam filling in the mouth significantly increased serum mercury and plasma miR-124-3p, miR-125-5p, and miR-127-3p levels in those participants.

Dental amalgam contains elemental mercury, which can evaporate at room temperature. All forms of mercury are toxic. Therefore, amalgam fillings carry a risk of both local and systemic side effects.26 Allergic reactions, oral lichen planus, gray-black discoloration in soft tissue, galvanic current due to contact with other metals have been stated that as local side effects of amalgam fillings. ${ }^{27}$ CNS is considered an organ in which the effect of mercury vapor is important. ${ }^{25}$ Mercury vapor may spread to the CNS, causing symptoms such as tremor, extreme irritability, forgetfulness, weakness, and visual disturbances. Kidney failure, peripheral neuropathy, and liver dysfunction may be observed later. ${ }^{28}$ Dentists are exposed to elemental mercury both from the making of amalgam and from their own amalgam fillings. ${ }^{29}$ Personal, office characteristics, and professional practice may also effect the level of mercury exposure..$^{30-33}$

In the present study, no statistical difference was found in the serum mercury and plasma miRNA values between the dentist and the control group. Significant positive associations between serum mercury and plasma miR-125-5p levels were detected in the dentist group. Previous presence of amalgam fillings and other sources of mercury exposure in the control group may have affected the results. One limitation of this study is the limited number of dentists who participated. It considered that results may vary with more dentist participants who perform amalgam filling more frequently. A positive correlation between mercury and miR-125-5p suggests that it may be a risk for neurological diseases. Another limitation of the study is that the participating dentists did not evaluate the working conditions. Variables related to working conditions (e.g., surface conditions, size of the place, ventilation, and type of equipment) have been reported to effect the level of mercury. ${ }^{34-36}$ Hock et al. reported higher blood mercury levels in Alzheimer's disease and major depression groups, regardless of the presence of amalgam fillings. They concluded that this may be due to other environmental exposure to mercury and should be investigated. ${ }^{10}$ The last limitation can be stated that there is no question about possible mercury exposure sources.

Researchers have reported significant positive correlation between the number of amalgam fillings per day and the occurrence of neuropsychological and muscular disorders (e.g., memory deficit, hand tremor, and irritability) in dentists. ${ }^{4}$ Dentists are exposed not only to mercury but also to many other chemicals (organic solutions, medical antiseptics, acrylate materials, etc.) throughout their professional life. ${ }^{37}$ Therefore, it is inaccurate to think that the symptoms are caused only by exposure to mercury. Exposure to other chemicals has also been reported to have an effect. ${ }^{4}$ Researchers have reported a positive relationship between higher blood mercury levels and elevated scores of psychoticism and anxiety (in SCL-90-R) and a negative correlation between logical memory (in the Wechsler Memory Scale-Revised test) and total retention score (in the Verbal Test of Memory Processes test) among dental personnel. ${ }^{25}$ Some neurobehavioral symptoms, decreased psychomotor speed, decreased cognitive flexibility, attention deficit, memory loss, fatigue, and sleep disorders have been explained to be related with mercury content in amalgam. ${ }^{15}$ Although no toxic cases have been reported, researchers report that dental amalgam may be associated with Alzheimer's Disease and Parkinson's disease with current data. ${ }^{38}$

Consistent with the literature, the serum mercury levels of patients with amalgam filling were higher than those of the other groups in the present study. This is considered to be the result of exposure to amalgam filling. In accordance with our findings, Pesch et al. found higher mercury levels in urine associated with the number of amalgam fillings and the number of amalgam filling surfaces.24 Unlike these researchers, Mc Grother et al. reported no positive relationship between body mercury content and the presence of amalgam filling and observed that the amount of filling was higher in patients with multiple sclerosis than in the controls. ${ }^{39}$ Although 
the relationship between dental amalgam and multiple sclerosis disease has not yet been proven, recent data suggest that repeated exposure to $\mathrm{Hg}$ vapor may increase the progression of MS through mitochondrial damage in recent experimental studies. ${ }^{40}$ There was no relationship between the number of amalgam fillings and the levels of serum mercury and plasma miR-124$3 p$, miR125-5p, and miR127-3p in the present study. This may be related to the number of amalgam fillings that the participants have, the number of filling surfaces, the duration of the filling in the mouth, and the presence of teeth that contribute to chewing function. In addition, the presence of patients who previously had teeth with amalgam filling and were included in the study after extraction of these teeth may have been effective in these results. The number of amalgam fillings and surface area were found to be positively correlated with mercury in the blood, which was significantly lower in the group without amalgam fillings. ${ }^{34}$ Additionally, general health complaints have been reported to decrease with the removal of amalgam fillings compared with the decrease in the previous urine mercury level. ${ }^{26}$ No difference was found in the mean neurobehavioral evaluation or nerve conduction velocity in children treated with amalgam filling compared with those treated with composite resin. ${ }^{41}$

MiRNAs have an important role in basic biological processes, such as apoptosis, proliferation, differentiation, improvement, and inflammation. ${ }^{42}$ One of the functions involving miRNAs is cell care, which is the processes involved in prenatal, postnatal, and adult CNS improvement. ${ }^{43}$ MiRNAs have important contributions in CNS development and neurodegenerative processes. ${ }^{44}$

MiR-124-3p is one of the subspecies of miR-124.45 MiR-124 was downregulated in AD brain, and it was associated with the generation and accumulation of amyloid beta. ${ }^{46,47}$ Researchers have reported that miR124-3p could have a neuroprotective effect on AD by inhibiting the hyperphosphorylation of tau-induced cell apoptosis. ${ }^{45}$ Similar studies have reported that miR124-3p overexpression has a neuroprotective effect on vitro models of Parkinson's disease. ${ }^{48}$ In the current study, the plasma miR-124-3p values were found to be higher in patients with amalgam filling than in the other groups. It has been shown that exposure to mercury through amalgam filling can cause a neurological effect.

One of the miRNAs that is upregulated during neurogenesis is miR-125b. ${ }^{44}$ MiR-125b specifically promotes the generation of dopaminergic neurons. ${ }^{49}$ The main sources of dopamine in the mammalian CNS are dopaminergic neurons in the midbrain. Their absence is associated with a neurological disease (i.e., Parkinson's disease).$^{50}$ Researchers have reported that miR-125b could support the continuation of differentiated neuronal cells by repressing apoptosis. ${ }^{51}$
The absence of miRNA-125b encourages the storage of mitotic cells, a raise in cell death, and a reduce in differentiation, whereas the overexpression of miR-125b has the reverse effect. ${ }^{51}$ Researchers have also reported that the overexpression of miR$125 \mathrm{~b}$ in long-term, self-renewing neuroepithelial-like stem cells weakens their self-renewal and provokes differentiation into neurons. ${ }^{52}$ In the present study, plasma miR-125-5p level was found to be higher in patients with amalgam filling than those in the other groups. Moreover, a positive correlation with serum mercury was detected in the group of patients with amalgam filling and the dentist group. Researchers have reported that changes in the expression of miR125 isoforms can have a significant effect on cell destiny. ${ }^{53}$

These results can be associated with the contribution to the neurogenesis process against neurodegeneration. It can be an advanced protection mechanism against mercury exposure.

One of the possible biomarker of different neurodegenerative diseases is MiR-127-3p. It was found to be upregulated in $A D$ serum and downregulated in $A D$ cerebrospinal fluid compared with the neurologically normal age-matched controls. $^{54}$ Moreover, it was upregulated in progressive multiple sclerosis patients compared with the controls.55 As with other miRNAs, plasma miR-127-3p values were significantly increased in patients with amalgam filling. Plasma miR-127-3p also showed a positive correlation with serum mercury. The increase in values due to the mercury content in the amalgam filling showed a predisposition to miRNAs in neurological diseases in people with amalgam filling.

\section{CONCLUSION}

Within the limitations of the study, the following conclusions were drawn:

- The levels of serum mercury and the plasma miRNAs associated with neurological diseases (124-3p, 125-5p, and 127-3p) were found to be significantly increased in patients with amalgam filling.

- The positive correlation between the serum mercury level and the plasma miR-125-5p and $127-3 p$ levels in patients with amalgam filling suggested that mercury exposure may be associated with neurological diseases.

- Long-term studies with more dentists are needed to clarify occupational mercury exposure in terms of neurological diseases.

- Alternative restorative materials should be preferred for amalgam filling and amalgam fillings should be replaced with biocompatible restorative materials under necessary preventions. 


\section{REFERENCES}

1. Chin G, Chong J, Kluczewska A, Lau A, Gorjy S. The environmental effects of dental amalgam. Aust Dent J 2000;45:246-9.

2. Counter SA, Buchanan LH. Mercury exposure in children: a review. Toxicol Appl Pharmacol 2004;198:209-30.

3. Berlin $M$, Zalups RK, Fowler BA. Mercury. In: Nordberg G, Fowler RA, Nordberg M, Friberg LT (eds). Handbook on the toxicology of metals. 3rd ed. Burlington: Academic Press, 2007.

4. Neghab M, Choobineh A, Zadeh JH, Ghaderi E. Symptoms of Intoxication in Dentists Associated with Exposure to Low Levels of Mercury. Ind Health 2011;49:249-54.

5. Rohling ML, Demakis GJ. A meta-analysis of the neuropsychological effects of occupational exposure to mercury. Clin Neuropsychol. 2006;20:108-132.

6. Langan DC, Fan PL, Hoos AA. The use of mercury in dentistry: a critical review of the recent literature. J Am Dent Assoc 1987;115:867- 80.

7. Yip HK, Li DK, Yau DC. Dental amalgam and human health. Int Dent J 2003;53:464-8.

8. Godfrey ME, Wojcik DP, Krone CA. Apolipoprotein E genotyping as a potential biomarker for mercury neurotoxicity. J Alzheimers Dis 2003;5:189-95.

9. Langworth S, Bjorkman L, Elinder CG, JärupL, Savlin P. Multidisciplinary examination of patients with illness attributed to dental fillings. J Oral Rehabil 2002;29:705-13.

10. Hock C, Drasch G, Golombowski S, Müller-Spahn $F$, Willershausen-Zönnchen B, Schwarz $P$, et al. Increased blood mercury levels in patients with Alzheimer's Disease. J Neural Transm 1998;105:59-68.

11.Chia S, Ong C, Lee S, Tsakok F. Blood concentrations of lead, cadmium, mercury, zinc, and copper and human semen parameters. Arch Androl. 1992;29:177-83.

12.Dursun A, Yurdakok K, Yalcin SS, Tekinalp G, Aykut $\mathrm{O}$, Orhan $\mathrm{G}$, et al. Maternal risk factors associated with lead, mercury and cadmium levels in umbilical cord blood, breast milk and newborn hair. The Journal of Maternal-Fetal \& Neonatal Medicine. 2016;29:954-61.

13.Fok TF, Lam HS, Ng PC, Yip AS, Sin NC, Chan IH, et al. Fetal methylmercury exposure as measured by cord blood mercury concentrations in a mother-infant cohort in Hong Kong. Environ Int. 2007;33:84-92.

14.Leung TY, Choy CMY, Yim SF, Lam CWK, Haines CJ. Whole blood mercury concentrations in subfertile men in Hong Kong. Aust $\mathrm{N} Z \mathrm{~J}$ Obstet Gynaecol. 2001;41:75-7.
15.Bjørklund G, Hilt B, Dadar M, Lindh U, Aaseth J. Neurotoxic effects of mercury exposure in dental personnel. Basic Clin Pharmacol Toxicol 2019;124:568-74.

16. Bilen J, Liu N, Bonini NM. A new role for microRNA pathways: modulation of degeneration induced by pathogenic human disease proteins. Cell Cycle 2006;5:2835-8.

17.Johnson R, Noble W, Tartaglia GG, Buckley NJ. Neurodegeneration as an RNA disorder. Prog Neurobiol 2012;99:293-315.

18.Lagos-Quintana M, Rauhut R, Yalcin A, Meyer J, Lendeckel $\mathrm{W}$, Tuschl $T$. Identification of tissuespecific microRNAs from mouse. Curr Biol 2002;12:735-9.

19. Krichevsky AM, King KS, Donahue CP, Khrapko K, Kosik KS. A microRNA array reveals extensive regulation of micro-RNAs during brain development. RNA 2003;9:1274-81.

20. Miska EA, Alvarez-Saavedra E, Townsend M, Yoshii A, Sestan N, Rakic P, et al. Microarray analysis of microRNA expression in the developing mammalian brain. Genome Biol 2004;5:R68.

21. Makeyev EV, Zhang J, Carrasco MA, Maniatis T. The microRNA miR-124 promotes neuronal differentiation by triggering brain-specific alternative premRNA splicing. Mol Cell 2007;27:435-48.

22.Le MT, Shyh-Chang N, Khaw SL, Chin L, Teh C, Tay J, et al. Conserved regulation of p53network dosage by microRNA-125b occurs through evolving miRNA-target genepairs. PLoS Genet 2011;7:e1002242.

23. Khudayberdiev SA, Zampa F, Rajman M, Schratt G. A comprehensive characterization of the nuclear microRNA repertoire of post-mitotic neurons. Front Mol Neurosci Epub ahead of print 17 Oct 2013. DOI: 10.3389/fnmol.2013.00043

24.Pesch A, Wilhelm M, Rostek U, Schmitz N, WeishoffHouben M, Ranft $U$, et al. Mercury concentrations in urine, scalp hair, and saliva in children from Germany. J Exposure Anal Environ Epidemiol 2002;12:252-8.

25.Aydin N, Karaoglanoglu S, Yigit A, Keles MS, Kirpinar I, Seven N. Neuropsychological effects of low mercury exposure in dental staff in Erzurum, Turkey. Int Dent J 2003;53:85-91.

26.Björkman L, Sjursen TT, Dalen K, Lygre GB, Berge TLL , Svahn J, et al. Long term changes in health complaints after removal of amalgam restorations. Acta Odontol Scand 2017;75:208-19.

27. Martin MD, Broughton S, Drangsholt M. Oral lichen planus and dental materials: a case-control study. Contact Dermatitis 2003;48:331-6.

28. Erkekoğlu P, Kadıoğlu E. Mercury Poisoning And Treatment. Toxicol Bull 2013;37:6-9. 
29. Heyer NJ, Echeverria D, Bittner AC, Farin FM, Garabedian CC, Woods JS. Chronic low-level mercury exposure, BDNF polymorphism, and associations with self-reported symptoms and mood. Toxicol Sci 2004;81:354-63.

30. Martin MD, Naleway C, Chou HN. Factors contributing to mercury exposure in dentists. J Am Dent Assoc 1995;126:1502-11.

31.Langworth S, Sallsten G, Barregard L, Cynkier I, Lind ML, Söderman E. Exposure to mercury vapor and impact on health in the dental profession in Sweden. J Dent Res 1997;76:1397-1404.

32.Dock L, Vahter M. Metal toxicology. In: Ballantyne B, Marrs TC and Syversen T (eds) General and applied toxicology. 2nd ed. London: Macmillan Reference Books, 1999.

33. Clarkson TW, Magos L, Myers GJ. The toxicology of mercury-current exposures and clinical manifestations. N Engl J Med 2003;349:1731-7.

34.Abraham J, Svare C, Frank C. The effects of dental amalgam restorations on blood mercury levels. J Dent Res 1984;63:71-73.

35. Nilsson B, Nilsson B. Mercury in dental practice the working environment of dental personel and their exposure to mercury vapor. Swed Den J 1986;10:1-14.

36. Molin M, Bergman B, Marklund SL, Schütz A, Skerfving $S$. Mercury, selenium and glutathine peroxidase before and after amalgam renoval in man. Acta Odontal Scand 1990;48:189-202.

37.Lindbohm ML, Ylöstalo $P$, Sallmén $M$, HenriksEckerman MJ, Nurminen T, Forss $\mathrm{H}$, Taskinen $\mathrm{H}$. Occupational exposure in dentistry and miscarriage. Occup Envirom Med 2007;64:12733.

38. Jirau-Colón H, González-Parrilla L, MartinezJiménez J, Adam W, Jiménez-Velez B. Rethinking the Dental Amalgam Dilemma: An Integrated Toxicological Approach Int J Environ Res Public Health 2019;16:1036.

39.McGrother CW, Dugmore C, Phillips MJ, Raymond NT, Garrick P, Baird WO. Multiple sclerosis, dental caries and fillings: a case-control study. Br Dent J 1999;187:261-4.

40.Kahrizi F, Salimi A, Noorbakhsh F, Faizi M, Mehri $F$, Naserzadeh $P$, et al. Repeated administration of mercury intensifies brain damage in multiple sclerosis through mitochondrial dysfunction. Iranian journal of pharmaceutical research: IJPR. 2016;15:834.

41. DeRouen TA, Martin MD, Leroux BG, Townes BD, Woods JS, Leitão J, et al. Neurobehavioral effects of dental amalgam in children: a randomized clinical trial. JAMA 2006;295:1784-92.

42. Li N, Pan X, Zhang J, Ma A, Yang S, Ma J, et al. Plasma levels of mir-137 and mir-124 are associated with parkinson's disease but not with parkinson's disease with depression. Neurol Sci 2017;38:761-7.
43. Kapsimali M, Kloosterman WP, De Bruijn E, Rosa F, Plasterk RHA, Wilson SW. MicroRNAs show a wide diversity of expression profiles in the developing and mature central nervous system. Genome Biol 2007;8:R173.

44.Diaz NF, Cruz-Resendiz MS, Flores-Herrera $H$, García-López G, Molina-Hernández A. MicroRNAs in central nervous system development. Rev Neurosci 2014;25:675-86.

45.Kang Q, Xiang Y, Li D, Liang J, Zhang X, Zhou F, et al. Mir-124-3p attenuates hyperphosphorylation of tau protein-induced apoptosis via caveolin-1pi3k/akt/gsk3beta pathway in n2a/app695swe cells. Oncotarget 2017;8:24314-26.

46. Smith P, Al Hashimi A, Girard J, Delay C, Hébert SS. In vivo regulation of amyloid precursor protein neuronal splicing by microRNAs. J Neurochem 2011;116:240-7.

47.Fang M, Wang J, Zhang X, Geng Y, Hu Z, Rudd JA, et al. The miR-124 regulates the expression of BACE1/beta-secretase correlated with cell death in Alzheimer's disease. Toxicol Lett 2012;209:94-105.

48.Dong RF, Zhang B, Tai LW, Liu HM, Shi FK, Liu NN. The Neuroprotective Role of miR-124-3p in a 6Hydroxydopamine-Induced Cell Model of Parkinson's Disease via theRegulation of ANAX5. J Cell Biochem 2018;119:269-77.

49.Barca-Mayo O, Tonelli DDP. Convergent microRNA actions coordinate neocortical development. Cell Mol Life Sci 2014;71:2975-95.

50.Chinta SJ, Andersen JK. Dopaminergic neurons. The Int J Biochemistry \& Cell Biology 2005;37:942-6.

51.Le MT, Xie H, Zhou B, Chia PH, Rizk P, Um M, et al. MicroRNA-125b promotes neuronal differentiation in human cells by repressing multiple targets. Mol Cell Biol 2009;29:5290-305.

52.Roese-Koerner B, Stappert L, Koch P, Borghese L. Pluripotent stem cell-derived somatic stem cells as tool to study the role of microRNAs in early human neural development. Curr Mol Med 2013;13:707-22.

53. Boissart C, Nissan X, Giraud-Triboult K, Peschanski M, Benchoua A. miR-125 potentiates early neural specification of human embryonic stem cells. Development 2012;139:1247-57.

54.Piscopoa P, Grassob M, Puopoloa M, D'Acunto E, Talarico G, Crestini A, et al. Circulating miR-127-3p as a Potential Biomarker for Differential Diagnosis in Frontotemporal Dementia. J Alzheimers Dis 2018;65:455-64.

55.Ebrahimkhani S, Vafaee F, Young PE, Hur SSJ, Hawke S, Devenney E, et al. Exosomal microRNA signatures in multiple sclerosis reflect disease status. Sci Rep 2017;7:14293. 
Funding information: Necmettin Erbakan University, Scientefic Research Section, Grant/Award Number: 181224003

Corresponding Author:

Makbule Tuğba TUNÇDEMiR

Necmettin Erbakan University

Faculty of Dentistry

Department of Restorative Dentistry

Konya, Turkey

Phone : +90 5064663675

E-mail : makbule.erkan@hotmail.com 